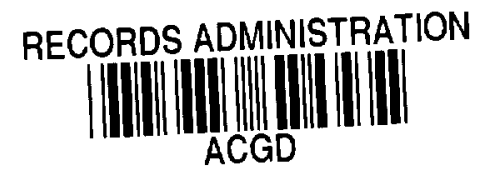

\title{
RESEARCH PRIORITIES FOR ISOLATION OF DEFENSE HIGH-LEVEL AND TRANSURANIC WASTES IN THE UNITED STATES
}

by

Donald E. Gordon

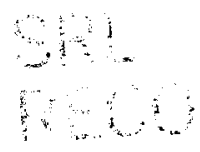

E. I. du Pont de Nemours and Company

Savannah River Laboratory

Aiken, South Carolina 29808

An invited paper'for presentation at the Fifth International

Symposium on the Scientific Basis for Radioactive Waste Management West Berlin, Germany

June 7-10, 1982

This paper was prepared in connection with work done under Contract No. DE-AC09-76SR00001 with the U.S. Department of Energy. By acceptance of this paper, the publisher and/or recipient acknowledges the U.S. Government's right to retain a nonexclusive, royalty-free license in and to any copyright covering this paper, along with the right to reproduce and to authorize others to reproduce all or part of the copyrighted paper. 


\section{RESEARCH PRIORITIES FOR ISOLATION OF DEFENSE HIGH-LEVEL AND TRANSURANIC WASTES IN THE UNITED STATES*}

Donald E. Gordon

E. I. du Pont de Nemours and Company

Savannah River Laboratory

Aiken, South Carolina 29808

\section{INTRODUCTION}

In the United States the Department of Energy has responsibility for the safe isolation of radioactive high-level wastes (HLW) and transuranic (TRU) wastes from the human environment. 1 The Department's preferred strategy for isolation of these wastes is multibarrier disposal in deep geologic repositories. ${ }^{2}$ However, in situ disposal for some of the older defense wastes which may offer more hazards in removal than in local isolation is being considered. Also, limited studies are being carried out on seabed and outer space disposal.

Over the last ten years the DOE has conducted a major research and development program to provide the technology needed for disposing of its high-level and transuranic wastes. This program has led 1) to the delineation of alternate disposal technologies, their risks and $\left.\operatorname{costs}{ }^{3-5} ; 2\right)$ to the characterization of a variety of high-integrity immobilization forms for both HLW 6 and TRU waste ${ }^{7}$;

* The information contained in this article was developed during the course of work under Contract No. DE-AC09-76SR00001 with the U.S. Department of Energy. 
3) to the development of fabrication technology for the waste forms, canisters, overpacks, and other engineered barriers ${ }^{8-10}$; 4) to the identification of preferred repository geologies 11 ; and 5) to very low assessments of disposal risks.12 Based on the results of this program, the DOE is now proposing to begin construction of the Defense Waste Processing Facility (DWPF) at Savannah River as the first HLW immobilization plant in the United States and of the Waste Isolation Pilot Plant (WIPP) as an R\&D facility for demonstrating the safe disposal of HLW and TRU waste. Highlevel waste repositories are being developed in the preferred salt, basalt, and tuff geologies. Defense TRU waste may be emplaced in the WIPP for final disposal.

Although the existing data base can now provide a firm foundation for these initiatives, considerable research and development is still required before the full disposal system can be put in place. This paper discusses the ongoing research and development needs as they apply to the disposal of nuclear wastes generated as byproducts of U.S. defense activities. A subsequent paper by H. C. Burkholder will address the corresponding research priorities for disposal of the HLW and TRU waste that may be generated from reprocessing of spent fuels from U.S. nuclear power reactors.

\section{DEFENSE HIGH-LEVEL WASTE}

High-level radioactive wastes (HLW) which have been generated from defense activities (Table 1) are stored in large underground tanks or bins at the defense sites at Savannah River, Hanford, and 
Idaho. ${ }^{13}$ The preferred waste disposal system for isolating these defense high-level wastes is illustrated in Figure 1. The separate steps are 1) immobilization of the HLW into a high-integrity solid waste form in a containment canister, 2) interim storage of the HLW canisters at the fabrication site, 3) transportation of the solidified waste to a repository, 4) packaging of the waste canisters and final emplacement of waste packages into the host rock, and 5) long-term geologic isolation.

Construction and operation of the facilities necessary to immobilize DOE defense wastes are scheduled on a sequential basis to alleviate cost impacts and to benefit from design and operating experience with the earlier facilities. 14 The sequence of construction is Savannah River, Hanford, and Idaho.

Seventeen candidate waste forms have been developed and characterized as potential media for geologic disposal of HLW. At the end of fiscal year 1981, two forms, borosilicate glass and crystalline ceramic, were selected for continued development in support of the Defense Waste Processing Facility (DWPF) at Savannah River, and in support of the overall program goal of immobilizing all HLW existing in the United States. 6 The choice between glass and ceramic as the DWPF waste form is scheduled to be made before the end of FY-1982.

The waste disposal system is now more clearly defined with the scheduled construction of an immobilization facility (DWPF) and with the development of repository geologies focusing on three 
leading candidates (salt, basalt, and tuff). The research needs for HLW isolation center around 1) the improvement in the technology for immobilizing the waste, 2) obtaining a better understanding of the performance of the waste package components in the repository environment, and 3 ) confirmation of waste disposal risk assessments and their application as the technical basis for regulatory criteria.

Borosilicate glass has been the reference waste form for the DWPF since 1977. The development of product and process technology for vitrifying the defense HLW at Savannah River has been continuing since then. Further development of immobilization technology is needed in several areas as outlined in Table 2.

Even though borosilicate glass has good chemical durability and mechanical strength, improvements in these properties are being pursued. Specifically glass quality improvements such as lower corrosiveness, less crystal formation, and lower volatility are desired. Reduction of glass cracking during processing needs more attention.

The reference process uses a liquid slurry fed ceramic melter. The melter is a major-equipment item, and replacement after failure is time-consuming and costly. Increasing the melter life is a development task which deserves further study.

Nondestructive testing of glass canisters and remote handling capability are important aspects of the immobilization facility. Development of these technologies is not complete and needs further attention. 
The retention of radionuclides within the waste storage system (Figure 2) will depend greatly on the interaction of the system components with the solid waste form and the mass transport properties of the species of interest under expected conditions. The waste storage system is defined as 1) solid waste form, 2) metal canister, 3) metallic or ceramic overpack, 4) retrieval sleeve, 5) mineralogic backfil1, and 6) stable geologic site. The research needs for determining the effects of system component interactions are given in Table 3.

First, detailed information on the specific sites for geologic isolation is required. Characterization of repositories is essential to define the environmental conditions to which the waste form and package will be subjected. Of particular interest are the ambient temperatures, lithostatic pressures, and flow rates, characteristics, and compositions of the groundwaters of potential geologic sites.

The leaching of nuclear waste forms is a complex phenomenon that has been studied extensively. There is a basic understanding of the various reactions involved. However, the specific mechanisms for corrosion of the waste forms need further study and confirmation. The release mechanisms provide the fundamental bases for predictive models on waste form performance. Important considerations for waste glass systems include the formation and stabilization of protective surface layers that form during leaching. 15 
Previous studies indicate that radionuclide migration from a geologic repository to the human environment is retarded by a variety of chemical and physical processes. The degree to which radionuclide movement is reduced or prevented by various coupling processes (i.e., ion exchange, sorption, etc.) needs better definition. The Environmental Protection Agency (EPA) has proposed regulations for high-level waste isolation in terms of total curies released to the accessible environment over a 10,000-year period. 16 The EPA has identified several radionuclides of concern and has specified release limits for these isotopes per metric ton of heavy metal charged to the reactor as given in Table 4. The behavior of these transuranics and fission products in the relevant geologic media should be better established.

The degree of long-term isolation of radioactive high-level waste provided by a repository can be adequately expressed only through mathematical modeling. Predictive models based on the behavior of the waste form and the appropriate geologic conditions have been proposed. Additional work is needed to ensure that all potential release mechanisms are considered and to provide confirmatory data for existing models. Federal regulatory criteria 17 relating to the performance of the engineered system in the repository have been drafted by the Nuclear Regulatory Commission (NRC). Mathematic models provide the means to demonstrate compliance with the NRC rule as finally adopted. 
Another aspect of radionuclide retention in the waste storage system that should be considered is the synergistic effects of the system components acting together. Any component which enhances waste form corrosion or counteracts the retardation processes in the geology needs to be identified and replaced with a suitable alternative. Likewise, improved performance in the waste storage system resulting from refinement, elimination, or replacement of the reference components is also important.

Assessments of the long-term risks of disposing of defense HLW in solid waste forms in geologic repositories indicate an insignificant impact on the human environment. Confirmation of these risk assessments would provide greater assurance of the long-term safety potential of geologic isolation of defense HLW (Table 5). Currently proposed regulatory criteria are only partially based on the potential environmental impacts of HLW disposal. Additional work is needed to establish risk assessment results as the scientific bases for the standards on radionuclide releases and radiation exposures.

The most immediate need in the DOE effort to define and develop a waste disposal system for defense HLW is a large-scale demonstration of waste immobilization. Of equal importance is the determination of repository performance for assessing long-term safety potential and conformance with final regulatory criteria. The research needs presented here address the relevant issues of waste immobilization technology and performance assessment of the waste disposal system. 


\section{DEFENSE TRANSURANIC WASTE}

Transuranic (TRU) wastes generated from defense activities have accumulated at several DOE sites as listed in Table 6.13 Prior to 1970 , waste disposal procedures did not require segregation of TRU waste from low-level waste, and a considerable volume of lowlevel waste that contained TRU elements was buried in shallow-1and burial at DOE sites. In 1970 the Atomic Energy Commission began to store retrievably all government transuranic waste containing TRU radioactivity greater than $10 \mathrm{nCi} / \mathrm{g}$. At the end of 1980 there were an estimated $61,000 \mathrm{~m}^{3}$ of retrievable waste stored at the DOE sites (also 1 isted in Table 4), primarily at Idaho. Only about one percent of the retrievable TRU waste requires remote handing.

The national plan for disposal of defense TRU waste is keyed to the demonstration and testing program at the Waste Isolation Pilot Plant (WIPP) near Carlsbad, New Mexico. The WIPP is being developed by DOE as a defense research and development activity. 18 The WIPP mission as authorized by federal legislation (Public Law 96-164) is "... for the express purpose of providing a research and development facility to demonstrate the safe disposal of radioactive waste resulting from defense activities and programs of the United States exempted from regulation by the Nuclear Regulatory Commission." One of the objectives of the WIPP experiment is a ful1-scale demonstration of TRU waste disposa ${ }^{\prime}$. This demonstration will include initial pilot emplacement operations of about $40,000 \mathrm{~m}^{3}$ of TRU waste in bedded salt. The full-scale demonstration will 
also include the shipment of waste to the site, handling, emplacement, and the capability for retrieval. The waste could, however, remain at the WIPP for final disposal.

The preferred waste disposal system for isolating retrievably stored TRU waste is shown in Figure 3. The specific stages of such a system (predicated on final disposal in WIPP) are 1) retrieval of the stored TRU waste, 2) inspection and classification as contact handled $(\mathrm{CH})$ or remote handled ( $\mathrm{RH})$ transuranic waste, 3) processing and packaging for disposal, 4) certification for conformance with waste acceptance criteria, 5) transportation of TRU waste packages to WIPP, 6) final emplacement of the waste packages into the bedded salt, and 7) long-term geologic isolation.

Decisions on the long-term management of buried TRU waste will be made individually for each site. The decisions must carefully consider the short and long-term risks of corrective action, and of the no action option. The current practice of careful monitoring at the burial sites is considered to be adequate for at least several decades. 19

Federal regulatory criteria on long-term containment in the waste package and low release limits that have been proposed for HLW isolation are not being applied to defense TRU waste disposal.17 With less stringent acceptance criteria and possible isolation in a nonlicensed salt repository, the research needs on TRU waste disposal are not as extensive as those for HLW. The technical issues relating to TRU waste isolation that need further study are discussed below (Table 7). 
The waste acceptance criteria for WIPP includes requirements on particulate content in the waste package. The fraction of waste particles with geometric diameters of 200 microns or less and 10 microns or less are 1 imited to 15 and 1 percent, respectively. This requirement was established to minimize the dispersion and respiration hazards should a waste container rupture during a handling or transportation accident. Methods to immobilize the TRU waste for dispersion control need further study.

Classification of $\mathrm{TRU}$ waste into $\mathrm{CH}$ and $\mathrm{RH}$ categories is an important step in the waste disposal system. Assay instrumentation is used to sort wastes to determine subsequent handling, to keep a reasonably reliable inventory, and to provide for safe, subcritical storage and handling arrangements. The development of accurate instrumentation for assaying the TRU content in waste needs additional research.

Nondestructive inspection of retrieved waste packages is another area of importance. Examination techniques to identify or verify the waste contents and container integrity require further development. Such methods as $\mathrm{x}$-ray and neutron radiography and ultrasonic testing have been suggested.

The research priorities for TRU waste isolation are focused on the development of processing technologies for waste immobilization and of improved instrumentation for classification and nondestructive examination. 
SUMMARY

Several research priorities relating to the isolation of $\mathrm{HLW}$ and TRU waste have been identified. For HLW, the research needs center around the improvement of waste immobilization technology, a better understanding of leaching mechanisms and the interactions among waste system variables, and establishment of risk assessments as the technical bases for regulatory criteria. For TRU waste, additional work on classification techniques and methods to immobilize particulates is suggested. 


\section{REFERENCES}

1. Nuclear Waste Management Program Summary Document, DOE/NE-0008, United States Department of Energy, Assistant Secretary for Nuclear Energy, March 1980.

2. Functional Requirements and Performance Criteria for Waste Packages for Solidified High-Level Waste and Spent Fuel, NWTS-33(4a), Battelle Memorial Institute, Office of NWTS Integration, April 1982.

3. Alternatives for Long-Term Management of Defense High-Level Radioactive Waste, ERDA-77-42/1, Energy Research and Development Administration, Savannah River Plant, May 1977.

4. Alternatives for Long-Term Management of Defense High-Level Radioactive Waste, ERDA-77-43, Energy Research and Development Administration, Idaho Chemical Processing Plant, September 1977.

5. Alternatives for Long-Term Management of Defense High-Level Radioactive Waste, ERDA-77-44, Energy Research and Development Administration, Hanford Reservation, September 1977.

6. The Evaluation and Selection of Candidate High-Level Waste Forms, DOE/TIC 11611, United States Department of Energy, Savannah River Operations Office, August 1981.

7. L. R. Crisler, A Preliminary Asessment of Nine Waste Form Products/Processes for Immobilizing Transuranic Wastes, RFP-3131, Rockwel1 International, Rocky Flats Plant, September 1980 .

8. T. H. Gould, et al, Assessment of Processes, Pacilities and Costs for Alternative Solid Forms for Immobilization of SRP Defense Waste, DP-1625, E. I. du Pont de Nemours and Co., Savannah River Laboratory, March 1982.

9 D. Newly, et al, Engineered Waste Package Conceptual Design, Defense High-Level Waste, Commercial High-Level Waste, and Spent Fuel Disposal in Salt, AESD-TME-3131 (Draft), Office of Nuclear Waste Isolation, Westinghouse Electric Corporation, November 1981.

10. NWTS Conceptual Reference Repository Description, Volume II, ONWI-258, Office of Nuclear Waste Isolation, Bechtel Group, Inc., May 1981. 
11. W. A. Carbiener, "NWTS Program Goals for 1982," Proceedings of the 1981 National Waste Terminal Storage Program Information Meeting, DOE/NWTS-15, United States Department of Energy, Office of NWTS Integration, November 1981.

12. H. Cheung, L. Edwards, T. Harvey, and M. Revel1i, Post Closure Risks of Alternative SRP Nuclear Waste Forms in Geologic Repositories, UCRL-87470 (Draft), Lawrence Livermore National Laboratory, April 1982.

13. Spent Fuel and Radioactive Waste Inventories and Projections as of December 31, 1980, DOE/NE-0017, United States Department of Energy, Assistant Secretary for Nuclear Energy, September 1981.

14. Strategy Document, Long-Term High-Level Waste Technology Program, DOE/SR-WM-79-3, United States Department of Energy, Savannah River Operations Office, May 1981.

15. G. G. Wicks and R. M. Wallace, "Leachability of Waste Glass Systems - Physical and Mathematical Models," Journal of Nuclear Materials, to be issued, 1982.

16. U.S. Code of Federal Regulations, Title 40, Part 191 (Draft), United States Environmental Protection Agency, Washington, DC.

17. U.S. Code of Federal Regulations, Title 10, Part 60 (Draft), United States Nuclear Regulatory Cormission, Washington, DC.

18. R. V. Matalucci, C. L. Christensen, T. O. Hunter, M. A. Molecke, and D. E. Munson, Waste Isolation Pilot Plant (WIPP) Research and Development Program: In Situ Testing Plan, SAND-81-2628 (Draft), Sandia National Laboratories, March 1982.

19. Transuranic (TRU) Waste Management Program Strategy Document, DOE/AL/TRU-8002, United States Department of Energy, Albuquerque Operations Office, July 1980. 
TABLE 1

United States High-Level Nuclear Wastes

(As of December 31, 1980)

Source

\author{
Hanford Plant \\ Idaho Chemical \\ Processing Plant \\ Savannah River Plant
}

Type

Alkaline

Cs/Sr Sources

Acid

Calcine

Alkaline $\frac{\text { Volume }}{\left(10^{3} \mathrm{~m}^{3}\right)} \quad \frac{\text { Radioactivity }}{\text { (Megacuries) }}$

183

200

358

9.3

2.1

17

96.7

700 


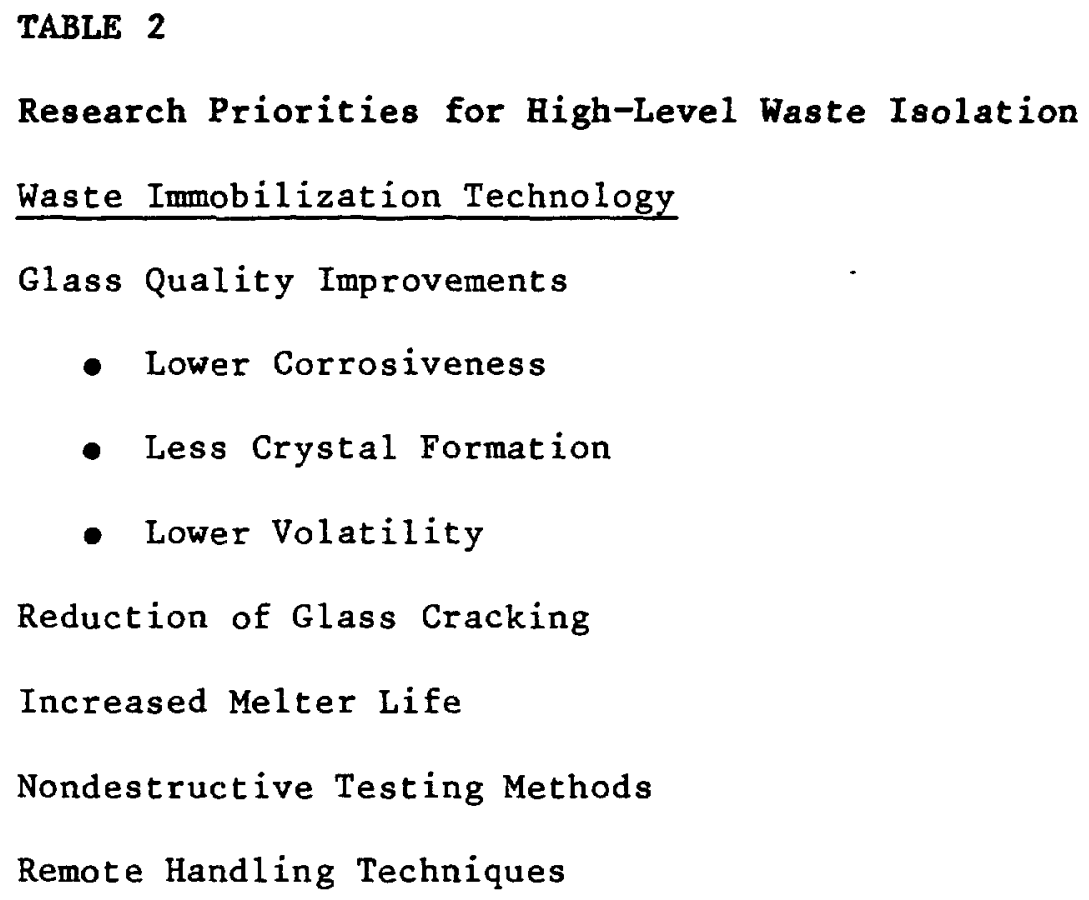


TABLE 3

Research Priorities for High-Level Waste Isolation

Waste System Performance

Repository Characterization

- Salt, Basalt, Tuff

- Environmental Conditions

Mechanisms of Waste Form Corrosion

- Surface Layer Formation/Stabilization

- Source Term

Radionuclide Migration in Geologic Media

- Retardation Factors

- Coupling Processes

Predictive Mathematical Models for Projecting Waste System Performance

- All Potential Mechanisms

- Confirmation of Existing Models

Synergistic Effects of Waste System Components 
TABLE 4

Cumulative Releases to the Accessible Environment for 10,000 Years after Disposal (40 CFR 191 Draft)

Radionuclide Release Limit

(curies per 1000 MTHM)

Americium-241 $\quad 10$

Americium-243 4

Carbon-14 200

Cesium-135 2000

Cesium-137 $\quad 500$

Neptunium-237 20

Plutonium-238 $\quad 400$

Plutonium-239 $\quad 100$

Plutonium-240 $\quad 100$

Plutonium-242 100

Radium-226 3

Strontium-90 80

Technetium-99 2000

Tin-126 80 


\section{TABLE 5}

Research Priorities for High-Level Waste Isolation

Risk Assessments of HLW Disposal

Confirmation of Risk Assessment Results

- Insignificant Environmental Impact

- Greater Assurance of Safety Potential

Establish Technical Basis for Regulatory Criteria 
TABLE 6

United States Transuranic Nuclear Wastes

(As of December 31, 1980)

DOE Site

Total Volume of Accumulated TRU Waste $\left(\mathrm{m}^{3}\right)$

Retrievably

Stored

TRU Waste $\left(\mathrm{m}^{3}\right)$

Hanford

178,000

10,556

Idaho National

99,500

42,387

Engineering Laboratory

Savannah River Plant

33,600

2,555

Los Alamos National Laboratory

15,900

4,366

Oak Ridge National Laboratory

7,180

948

Nevada Test Site

235

235

Sandia National Laboratories

3 
TABLE 7

Research Priorities for Transuranic Waste Isolation

Methods for Immobilization of Particulates

Development of Assay Instrumentation for Classification

- Contact Handled TRU Waste

- Remote Handled TRU Waste

Nondestructive Inspection of Waste Packages 


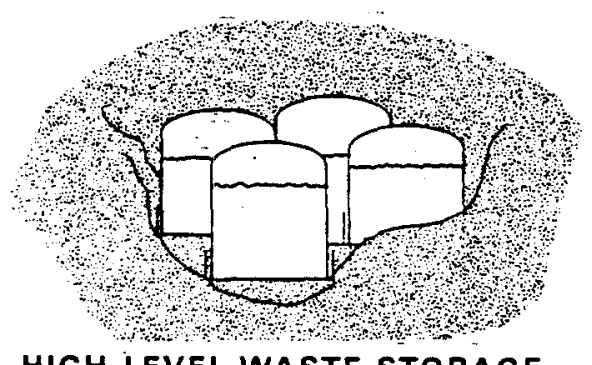

HIGH-LEVEL WASTE-STORAGE
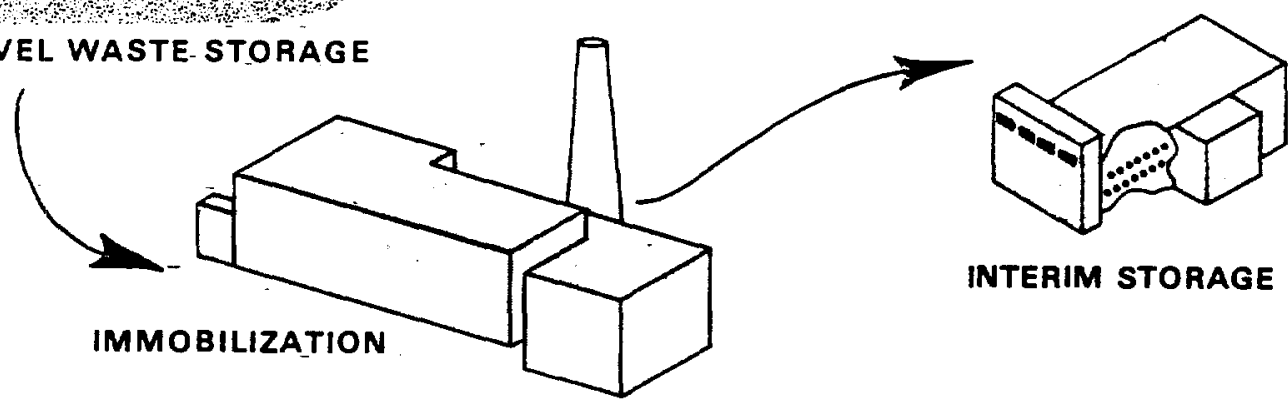

INTERIM STORAGE

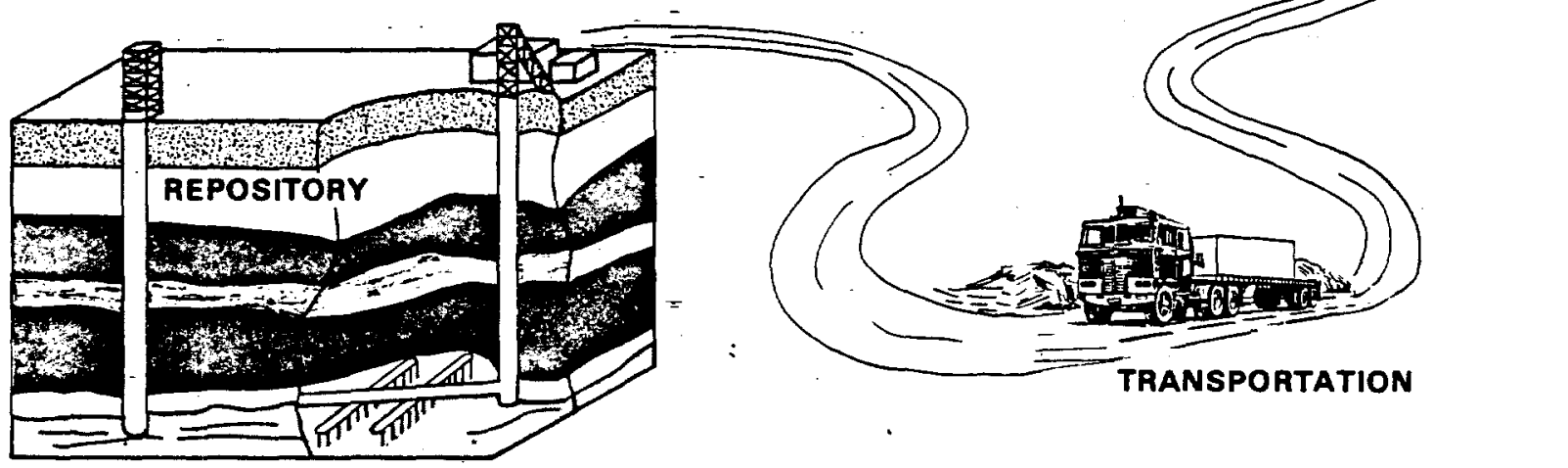

FIGURE 1. High-Level Waste Disposal System 


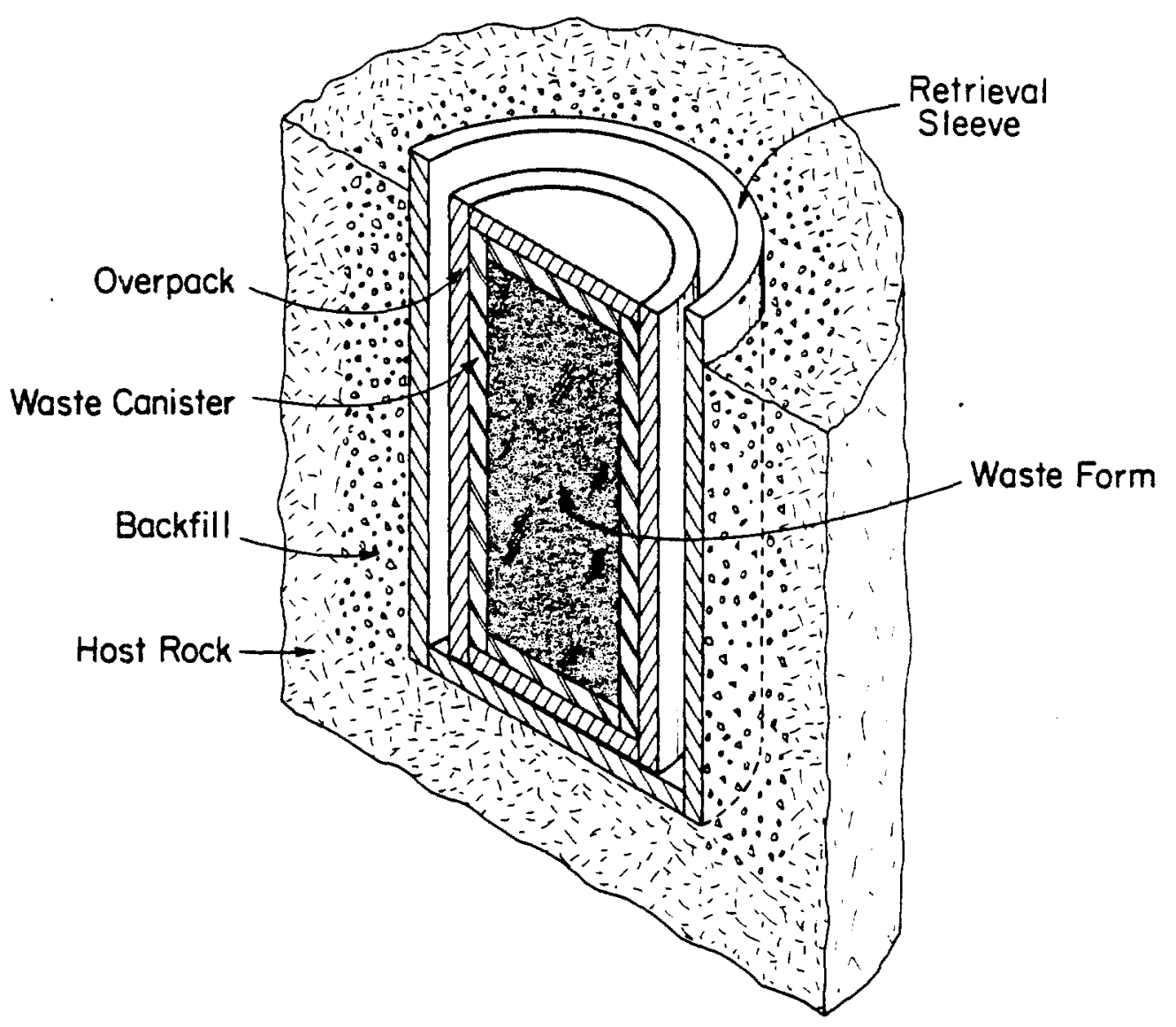

FIGURE 2. Waste Storage System 


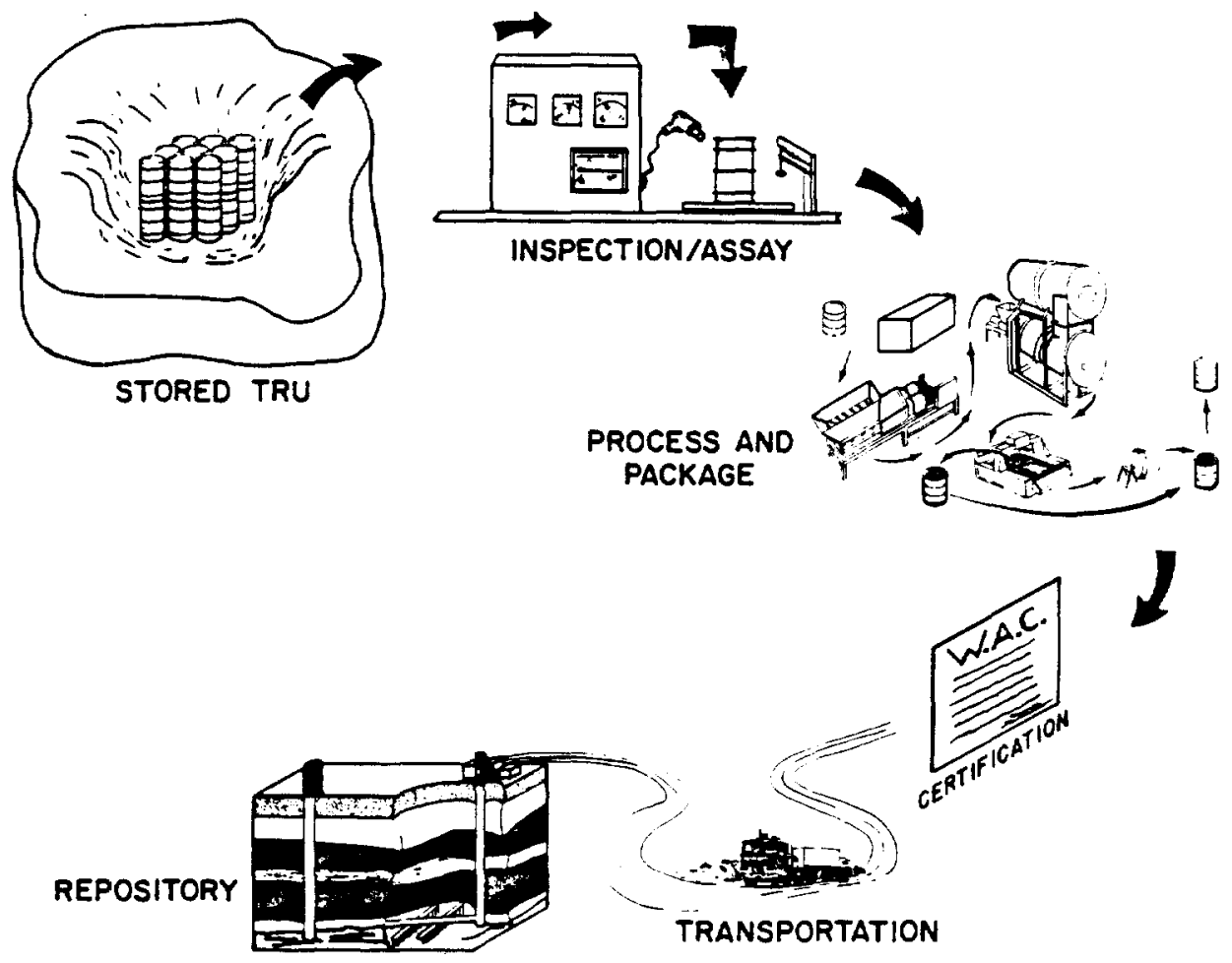

FIGURE 3. Transuranic Waste Disposal System 